\title{
INFLUENCE OF ABUSED BY FAMILY MEMBERS ON MORAL AND MARITAL STATUS OF A GIRL-CHILD IN CROSS RIVER STATE, NIGERIA
}

\author{
Afu, M. O \\ Department of Counselling and Educational Psychology \\ Faculty of Education, University of Abuja, Abuja-Nigeria.
}

\begin{abstract}
This study explored the current status of girl-child abused by family members and to see possible influences on their moral and marital status. The design adopted for this study is a descriptive survey research design. The population of the study comprises of 51,197 secondary school students who enrolled in 2018/2019 academic session in all the public senior secondary schools in in Cross River State. A sample of 381 respondents was selected for this study based on the Krejcie and Morgan (1970) sample table of specification. The proportionate random sampling procedure was used in selecting the students from different secondary schools to cut across relatively the population. The instrument for data collection titled: Girl Child Abuse Questionnaire (GCAQ). The GCAQ is a 30-item instrument designed along a fourpoint Likert scale. The questionnaire was validated by consulting experts and items that were considered to be vague and irrelevant were removed to ensure validity. To establish the reliability of the instrument, a pilot test was conducted. Using the test retest method of reliability, the two sets of scores obtained from the pilot test were correlated using Pearson Product Moment Correlation (PPMC). The reliability ( $r$ ) value of 0.76 was obtained for the scores which implied the high reliability of the instrument. The data collected was analysed using descriptive statistics. The study found that girl-child in the study area is abused by family members and this in turn affects their moral and marital status. It was recommended among other that government through her agencies should ensure that girls are given adequate attention; stiffer punishment be given to the perpetrators of this ugly act.
\end{abstract}

KEY WORDS: girl-child, abuse, marital status, moral status.

\section{INTRODUCTION}

Girl child abuse can be seen as a situation whereby the fundamental human right of a girl child is tempered with. That is, the child is not given adequate care and protection as it is the responsibility of every parent to take good care of their children. These rights are right to education, religion, freedom of movement, shelter etc (Awosusi \& Adebo, 2012). The girl child on most occasions is exposed to unnecessary hardship and odds in life. For example, the girl child is sexually abused and works in different sectors such as farms, domestic help, in fishing and street hawking (Adegun, 2013).

Gorey and Leslie (2007) assert that girl child abuse potentially has major social and psychological implications for the girl child in school. It was estimated that majority of Nigeria girl child experience sexual abuse before age 18, while 17 percent experience physical abuse, and 18 percent experience neglect. Shonk and Cicchetti (2001) relate that the current state of evidence for a link between girl child abuse (physical and sexual abuse or neglect) and school performance is negative associations between maltreatment and school performance. Shonk and Cicchetti (2001) reveal that children who are maltreated receive lower ratings of 
performance from their school teachers, score lower on cognitive assessments and standardized tests of academic achievement, obtain lower grades, and get suspended from school. Abused children are also prone to difficulty in forming new relationships with peers and adults and in adapting to norms of social behaviour.

Girl child abuse is a major life stressor that has consequences involving the mental health of the abused child. It has been identified that childhood sexual abuse is a risk factor for the development of substance-related problems during adolescence and adulthood. The early experiences of a girl child abuse can trigger the development of an internalizing disorder, such as anxiety and depression. For example, adults with a history of some form of child abuse, whether sexual abuse, physical abuse, or neglect, have more chances of developing depression than an adult who has never been abused (Gorey and Leslie, 2007). However, this paper will explain who a girl child is, examine the concept of girl child abuse, theoretical frame, and highlight the types of girl child abuse, its causes and effects. Finally, recommendations on how to curb the evils of girl child abuse are proposed.

Girl child abuse can occur in a child's home, or in the organizations, schools or communities the girl child interacts with. There are four major categories of girl child abuse: neglect, physical abuse, psychological/emotional abuse, and child sexual abuse. Herrenkohl (2005) defines girl child abuse as "any recent act or failure to act on the part of a parent or caretaker which results in death, serious physical or emotional harm, sexual abuse or exploitation, an act or failure to act which presents an imminent risk of serious harm".

According to Hughes (2009), girl child abuse is a situation whereby the fundamental human right of a girl child is tempered with. That is, the child is not given adequate care and protection as it is the responsibility of every parent to take good care of their children. These rights are right to education, religion, freedom of movement, shelter etc. The child on most occasions is exposed to unnecessary hardship and odds in life. Girl child abuse is more than sexual abuse, bruises and broken bones. While physical abuse might be the most visible sign, other types of abuse, such as emotional abuse or child neglect, also leave deep, long lasting scars on the victims. The earlier abused children get help, the greater chance they have to heal from their abuse and not perpetuate the cycle.Several studies have stressed the impact of teaching experience on teachers' attitude, which includes:

Abubakar and Okhloho (2016) conducted a study on Girl Child Abuse: Implication for Womanhood in Abuja, Nigeria. The result shows that this form of abuse constitutes a threat to the girl child in the form of brain injury, school dropout, and teenage pregnancies, among others. Taniya, Khagi, Krishna, Kupana and Rajendra (2019) conducted a study on Awareness on Girl Child Abuse Among mothers of a selected community in Nepal. The study revealed that that majority of mothers $224(77.8 \%)$ had average level of awareness regarding girl child abuse and only $21(7.3 \%)$ had good level of awareness with mean score \pm SD of $45.94 \pm 9.94$ (total score-76). Awareness of mother on girl child abuse was found significantly associated with age, ethnicity, educational status, type of family, age at marriage and number of children at $\mathrm{P}<0.05$.

Lima and Manilkandan (2013) conducted a study on Prevalence of Girl Child Abuse in Kerala: An Analysis in India. The result revealed that that there is greater number of girl child abuses 
occurring than is reported by media and in majority of the cases it was the immediate family member (nearly $36 \%$ father) who is the abuser/offender. The age of victims varies from 4 to 16 years. Out of 14 cases reported, 5 of them were abused by their father himself.

\section{Statement of the Problem}

Every girl-child is likened to an incubator that gives life to its contents, reproduce and modify her content for continuity. This same girl-child is vulnerable in most of the most communities in Nigeria especially in Cross-rive state. Girl-child are abused and marginalized in many forms by many people in the society.

Even as ugly as this girl-child abuse is, it has become norm for family members to abuse this set of gender for selfish interests. The reports on the media on this subject matter are alarming and it continues unabated, it may affect the moral and marital status of girl-child in Nigeria, especially in Cross River state. This is worrisome and this prompted the researcher carry out this study on the influence of abuse of family members on the moral and marital status of girlchild in Cross River state, Nigeria.

The following questions are raised to guide the research:

i. What are the incidences of girl-child abuse by family members is Cross River state Nigeria?

ii. What is the effect of Girl-child abuse by family members on the morals of the girl-child in Cross River state, Nigeria?

iii. What is the effect of abuse by family members on the marital status of the girl-child in Cross River state, Nigeria?

The study hypothesized that there is no significant relationship between abuse and the morality of the girl-child in Cross River state, Nigeria.

\section{METHODOLOGY}

The research design that was adopted for this study is the descriptive survey. The population of the study comprises of 51,197 secondary school students who enrolled in 2018/2019 academic session in all the public senior secondary schools in in Cross River State. The sample size for the study is 381 students based on the Krejcie and Morgan (1970) sample table of specification. The proportionate random sampling procedure was used in selecting the students from different secondary schools to cut across relatively the population. The instrument for data collection titled: Girl Child Abuse Questionnaire (GCAQ). The GCAQ is a 30-item instrument designed along a four-point Likert scale. The questionnaire was validated by consulting experts and items that were considered to be vague and irrelevant were removed to ensure validity. To establish the reliability of the instrument, a pilot test was conducted. Using the test retest method of reliability, the two sets of scores obtained from the pilot test were correlated using Pearson Product Moment Correlation (PPMC). The reliability (r) value of 0.76 was obtained for the scores which implied the high reliability of the instrument. The questionnaire was administered directly on the respondents by the researchers. The tools that were used in analysing the collected data include mean scores and Correlational statistics. 


\section{RESULTS}

Research Question One: What are the incidences of girl-child abuse by family members in Cross River state Nigeria?

Table 1: Incidences of Girl-child abuse by family members in Cross River state, Nigeria.

\begin{tabular}{llll} 
N=381 & & & \\
\hline $\mathbf{S} / \mathbf{N}$ & Statements & Mean & Decision \\
\hline 1 & $\begin{array}{l}\text { Some children are sexually abused by older children } \\
2\end{array}$ & $\begin{array}{l}\text { Most people who sexually abuse children do not belong to } \\
\text { the child's family. }\end{array}$ & Agree \\
3 & $\begin{array}{l}\text { Most of the time children are sexually abused when they are } \\
\text { alone, at night, and outside their home }\end{array}$ & Agree \\
4 & $\begin{array}{l}\text { Only girls are victims of sexual abuse } \\
5\end{array}$ & $\begin{array}{l}\text { Girl children from reputable families are not victims of } \\
\text { sexual abuse. }\end{array}$ & Agree \\
6 & $\begin{array}{l}\text { Children who report being victims of sexual abuse are not } \\
\text { necessarily placed in foster care following these revelations }\end{array}$ & Disagree \\
7 & $\begin{array}{l}\text { Few children are victims of sexual abuse } \\
8\end{array}$ & Only young girls-children are victims of abuse & Agree \\
& Sectional Mean & 2.34 & Disagree \\
\end{tabular}

Table 1 shows the incidences of girl-child abuse by family members in Cross River state. The sectional mean of 2.50 shows that the respondents agreed that there are cases of girl-child abuse by family members in Cross River state, Nigeria.

Research Question Two: What is the effect of Girl-child abuse by family members on the morals of the girl-child in Cross River state, Nigeria?

Table 2: Effect of Girl-child abuse by family members on morals of the girl in Cross River state, Nigeria.

$\mathrm{N}=381$

\begin{tabular}{|c|c|c|c|}
\hline $\mathbf{S} / \mathbf{N}$ & Statements & Mean & Decision \\
\hline 9 & $\begin{array}{l}\text { If or when an elderly man had sex or attempt to have sex with } \\
\text { me either by force or seduction and the aftermath worries my } \\
\text { conscience. }\end{array}$ & 3.33 & Agree \\
\hline 10 & Abused girls tend to hate men at all point & 3.56 & Agree \\
\hline 11 & $\begin{array}{l}\text { If a girl is abused by the family member, she may lack } \\
\text { respect for the family members }\end{array}$ & 3.48 & Agree \\
\hline 12 & Most abused girls may likely engage in prostitution & 2.65 & Agree \\
\hline \multirow[t]{2}{*}{13} & An abused girl does not have a sense of humility & 3.45 & Agree \\
\hline & Sectional Mean & 3.29 & \\
\hline
\end{tabular}

Table 2 shows the effects of girl-child abuse by family members on the morals of the girl-child in Cross River state. The sectional mean of 3.29 shows that the respondents agreed that there 
are effects of girl-child abuse by family members on the morals of the girl-child in Cross River state, Nigeria. Some of the effect of girl-child abuse may have worries and depression; more so, she may not have regards for marriage as sees every man as threat to her well-being.

Research Question Three: iii. What is the effect of abuse by family members on the marital status of the girl-child in Cross River state, Nigeria?

Table 3: Effect of Girl-child abuse by family members on marital status of the girl in Cross River state, Nigeria.

\begin{tabular}{llll}
$\mathrm{N}=381$ & & & \\
\hline $\mathbf{S} / \mathbf{N}$ & Statements & Mean & Decision \\
\hline 14 & Some abused girl-child will not agree to marry & 3.45 & Agree \\
15 & Abused girls ends up in a broken marriage & 2.46 & Disagree \\
16 & $\begin{array}{l}\text { If a girl is abused by the family member, she may trust any } \\
\text { man to marry her. }\end{array}$ & 3.48 & Agree \\
17 & Abused girls always rude to their husbands & 2.65 & Agree \\
18 & An abused girl-child always live in trauma in marriage & 3.46 & Agree \\
& Sectional Mean & $\mathbf{3 . 1 0}$ &
\end{tabular}

Table 3 shows the effects of girl-child abuse by family members on the marital status if the girl-child in Cross River state. The sectional mean of 3.10 shows that the respondents agreed that there are effects of girl-child abuse by family members on the marital status of the girlchild in Cross River state, Nigeria.

\section{DISCUSSION OF FINDINGS}

The result from the study showed that there are incidences of girl-child abuse by the family members in Cross River State. This may not be surprise due to the kind of cultural belief that girl-child is subjected to; seen as a second class child. This is not far from the findings of Lima and Manilkandan (2013) whose findings revealed that that there is greater number of girl child abuses occurring than is reported by media and in majority of the cases it was the immediate family member (nearly $36 \%$ father) who is the abuser/offender.

The study further indicated that girl-child abuse contribute to moral decay among girls in Cross River State, include hatred, lack of respect, quarrels and prostitution amongst others. When these mentioned factors are in in girls, there is every possibility that the girls will not be morally upright. This again is being collaborated by Abubakar and Okhloho (2016), who in their study found that this form of abuse constitutes a threat to the girl child in the form of brain injury, school dropout, and teenage pregnancies, among others. The study further revealed that most of the girls abused by family members find it difficult to cope with marital demands as most had lost the sense of love and are threatened with high level of insecurity and distrust from anybody around them. This is as a result of the fact that gender contribute to the kind of experience these girls encounter in Cross River State, Nigeria. 


\section{CONCLUSION AND RECOMMENDATIONS}

Based on the findings, the study concluded that, girls in Cross River State are abused by family members. The condition that contribute to immoral behaviours in the society, such as frustration, prostitution amongst others. The study concluded girl-child abuse by family members leads to distrust, frustration and marital instability.

The following recommendations are made based on the findings of this study:

1. The study recommended that government through her agencies should ensure that girls are given adequate attention.

2. The study recommended that agencies of government in charge of girl-child should make the welfare of girls a priority.

3. The study recommended that stiffer punishment be given to the perpetrators of this ugly act.

4. The study recommended that awareness should be created on the importance and the right of girl-child.

\section{REFERENCES}

Abubakar, M. \& Okloho, J. (2016) Girl Child Abuse: Implication for Womanhood. Capital Journal of Education Studies (CAJES), 4(1) pp.1-14.

Awosusi,O and Adebo, G.M. (2012). Domestic Servants and Rural-Youth Urban Migration in Nigeria. International Journal of Humanities and Social Science. 2 (5): 271-278.

Adegun, O. A. (2013) Practices of Child Labour among Parents in Ekiti State, Nigeria: Implication for School Administrators. Journal of Education and Practice. 4 (11)1-7.

Gorey, K.M. \& Leslie, D.R. (2007). The Prevalence of Child Sexual Abuse: Integrative Review Adjustment for Potential Response and Measurement Biases. Journal of Child Abuse \& Neglect. 21 (4), 391-8.

Shonk, S.M. \& Cicchetti, D. (2001). Maltreatment, Competency Deficits, and Risk for Academic and Behavioural Maladjustment. Journal of Developmental Psychology. 37(1), 3-17.

Krejcie, R. V., \& Morgan, D. W. (1970). Determining Sample Size for Research Activities. Educational and Psychological Measurement, 30, 607-610. 